\title{
Neuropharmacology in Pediatric Brain Injury: A Review
}

\author{
Percival H. Pangilinan, MD, Angela Giacoletti-Argento, PhD, Renee Shellhaas, MD, \\ Edward A. Hurvitz, MD, Joseph Edward Hornyak, MD, PhD
}

In this review, the current evidence is examined regarding neuropharmacologic treatment for children and adolescents (under the age of 18 years) who sustained a traumatic brain injury (TBI). Although the focus is on the pediatric TBI population, there is a paucity of empirical data related to the role of medication with children and adolescents after brain injury. Therefore, findings from the adult TBI literature are incorporated where appropriate so as to identify potential agents that warrant further examination in pediatric populations. This review addresses specific sequelae of TBI from the earliest stages of neurologic recovery to long-term comorbidities, including disorders of impaired consciousness, post-TBI agitation, cognitive decline, and post-TBI depression. The evidence regarding the role of medication in neuroprotection and neurorecovery in this population is also explored. Medication classes reviewed include excitatory amino acids, antagonists to the N-methylD-aspartate receptor, dopamine agonists, benzodiazepines, $\beta$-blockers, anticonvulsants, and antidepressants. It is hoped that this review will guide future research, and ideas as to how this may be accomplished within a pediatric population are suggested.

PM R 2010;2:1127-1140

\section{INTRODUCTION}

In children, traumatic brain injury (TBI) severe enough to require hospitalization is estimated at 70 per 100,000. The highest incidence and greatest morbidity and mortality occur in youth aged 15-17 years [1]. In 2007, of an estimated 73.7 million children in the United States [2], approximately 51,000 pediatric TBIs occurred. Approximately 10\% of these children were hospitalized for more than 10 days, which suggests that they sustained severe TBI [1]. Severe TBI and, to a lesser extent, mild and moderate TBI result in numerous long-term impairments in motor functioning, behavior, and cognition. Over the past several years, pharmacologic intervention for TBI has become more popular within adult populations. The goals of treatment are generally to increase attention and general cognitive performance, and to normalize behavior [3]. Pediatric rehabilitation specialists and other physicians treating children and adolescents with TBI have also begun to use medications to enhance rehabilitation outcomes. This review article focuses on pharmacologic interventions aimed at improving outcomes after pediatric TBI. Where the literature is scant or nonexistent, findings from adult TBI are summarized. (For a recent review of pharmacologic treatment of adults with TBI, the reader is referred to Crooks et al [3].) Because there is a dearth of well-controlled studies in this area, it is hoped that the present article will guide future research and clinical investigations. This article is organized around common states and symptoms encountered in the recovery process, from the acute phase forward (Table 1). In addition, Tables 2-7 summarize information about specific agents by drug class.

\section{NEUROPROTECTIVE AGENTS}

Research into the neurotoxic cascade apparent after TBI has informed the use of neuroprotective agents during the acute phase of recovery [4]. Excitatory amino acids (eg, glutamate and glycine) have been shown to be elevated after brain injury, which suggests that they may play a role in secondary metabolic injury [5]. The N-methyl-D-aspartate (NMDA) receptor
P.H.P. Department of Physical Medicine and Rehabilitation, University of Michigan, Ann Arbor, MI

Disclosure: nothing to disclose

A.G.-A. Department of Physical Medicine and Rehabilitation, University of Michigan, Ann Arbor, Ml

Disclosure: nothing to disclose

R.S. Division of Pediatric Neurology, Department of Pediatrics, University of Michigan, Ann Arbor, MI

Disclosure: nothing to disclose

E.A.H. Department of Physical Medicine and Rehabilitation, University of Michigan, Ann Arbor, MI

Disclosure: nothing to disclose

J.E.H. Department of Physical Medicine and Rehabilitation, University of Michigan, $325 \mathrm{E}$. Eisenhower, Ann Arbor, Ml 48108. Address correspondence to: J.E.H.; e-mail: jhornyak@ med.umich.edu

Disclosure: nothing to disclose

Disclosure Key can be found on the Table of Contents and at www.pmrjournal.org

Submitted for publication December 15, 2009; accepted July 5, 2010. 
Table 1. Medications referenced

Neuroprotective agents
N-methyl-D-aspartate antagonists
Ketamine, memantine, amantadine
nAch-r agonists
Donepezil
Anticonvulsants
Carbamazepine
Phenytoin
Lamotrigine
Levetiracetam
Topiramate
Valproic acid
Impaired arousal
Dopamine agonists
Carbidopa-levodopa, amantadine, bromocriptine,
pramipexole, methylphenidate, amphetamine,
apomorphine
Omega 1-specific indirect GABA agonists
Zolpidem
Intrathecal baclofen
Agitation
Benzodiazepines
Midazolam, alprazolam, lorazepam, diazepam,
clonazepam
$\beta$-Blockers
Propranolol
Anticonvulsants
Valproic acid, carbamazepine, lamotrigine, topiramate,
levetiracetam
Antidepressants
Amitriptyline, sertraline, citalopram, paroxetine, fluoxetine
Antipsychotics
Clozapine, risperidone, quetiapine, ziprasidone,
olanzapine, haloperidol, droperidol
Cognitive impairments
Methylphenidate, amphetamine-derivatives, nAch-r
agonists
Tricyclic antidepressants
Imipramine, amitriptyline, desipramine, nortriptyline,
Selinamine

GABA $=\gamma$-aminobutyric acid; $n A c h-r=$ nicotinic acetylcholine receptor.

has been a target of investigation over the last few decades. Although early work in animals suggested benefit of NMDA blockade [6], these findings have been inconsistent in subsequent animal trials $[7,8]$ or later clinical trials [9-11]. Ketamine, memantine, and amantadine are strong, moderate, and weak antagonists, respectively, to the NMDA receptor currently available in the United States (Table 3). Amantadine will be discussed in more depth later in this article. Although memantine has been used clinically in both children and adults with TBI, there are no formal studies or case reports (the primary literature in TBI neuropharmacology) documenting the efficacy of memantine in TBI, as of March 2010. In addition, evidence that NMDA antagonists promote apoptosis by blocking the excitatory effects of glutamate in young rats [8] raises concerns that this class of medications may contribute to further secondary brain injury in children. Finally, because excitatory neurotransmitters (eg, glutamate) are necessary for neural development and plasticity, concern has been raised that medications in this class could actually inhibit recovery from TBI. It is uncertain whether amantadine, as a weak antagonist, carries these same risks.

Another class of medications being investigated for neuroprotective effects is the nicotinic acetylcholine receptor (nAch-r) agonists. Results with donepezil suggest a neuroprotective effect from concussive brain injury [12] and ischemia [13] in rats. For ischemic injury, the nAch-r agonist was given 2 hours before injury. In TBI, the greatest neuroprotective effect was seen when a relatively high dose was given at the time of injury. Although these studies offer some hope for preventing secondary injury, much more research needs to be done before instituting use of nAch-r agonists in the pediatric TBI population.

Given the high incidence of post-traumatic epilepsy among pediatric TBI survivors [14], there has been increasing interest in determining whether anticonvulsant treatments could be neuroprotective, in addition to preventing seizures. Currently, prophylactic anticonvulsant medications are not recommended for prevention of late post-traumatic epilepsy among children [15], although treatment with phenytoin or levetiracetam can decrease the risk of early post-traumatic seizures [16]. In a study of adults with severe TBI, levetiracetam was safe, had fewer adverse effects, and was associated with better cognitive outcomes compared with phenytoin [17]. A single dose of levetiracetam was found to be neuroprotective and superior to phenytoin in a rat model of TBI [18], and this drug is believed to have antiepileptogenic effects based on several animal models of seizures [19]. These promising findings have not yet been extended to children, but there is great interest in the possibility of using levetiracetam as both a neuroprotective and anticonvulsant medication in children with TBI.

Topiramate is another anticonvulsant with probable neuroprotective effects. By lowering glutamate levels, this agent could modify the excitatory adverse effects of this neurotransmitter after TBI. In adult humans, Alves et al [20] demonstrated, by cerebral microdialysis, a dose-response effect whereby topiramate decreased cerebrospinal fluid (CSF) glutamate levels after TBI. In a study of adult rats, topiramate administered after TBI did not impact acute posttraumatic cerebral edema or histologic injury and was associated with poorer cognitive outcomes but improved motor functioning at 1 and 4 weeks after fluid percussion injury [21]. In humans with TBI, there have been concerns about cognitive adverse effects associated with topiramate [22]. The anorexic adverse effects of this medication could benefit those patients with TBI and obesity [23] but may be contraindicated in others. Thus, although there are suggestions that 
Table 2. Catecholaminergic agents

\begin{tabular}{|c|c|c|c|c|c|c|c|}
\hline Medication & $\begin{array}{l}\text { FDA Approval in } \\
\text { Pediatric } \\
\text { Patients }\end{array}$ & FDA Pediatric Dosages & $\begin{array}{c}\text { Mechanism of } \\
\text { Action }\end{array}$ & FDA Indications & TBI Usage & Serious Reactions & Warnings \\
\hline Amantadine & $\begin{array}{l}\text { Yes, > } 1 \text { y of age } \\
\text { (influenza only) }\end{array}$ & $\begin{array}{l}\text { Ages 1-9 y: } 2.2-4.4 \mathrm{mg} / \\
\text { kg BID, up to } 75 \mathrm{mg} \\
\text { BID; >9 y: } 100 \mathrm{mg} \text { BID, } \\
\text { typically start at } 1 / 2 \\
\text { lowest dose, titrate to } \\
\text { maximum }\end{array}$ & $\begin{array}{r}\text { Dopamine agonist, } \\
\text { NMDA antagonist }\end{array}$ & $\begin{array}{l}\text { Influenza A, } \\
\text { parkinsonism, } \\
\text { extrapyramidal } \\
\text { reactions }\end{array}$ & $\begin{array}{l}\text { Arousal from coma } \\
\text { or minimally } \\
\text { conscious states }\end{array}$ & $\begin{array}{l}\text { Neuroleptic malignant } \\
\text { syndrome with } \\
\text { abrupt withdrawal, } \\
\text { exacerbation of } \\
\text { congestive heart } \\
\text { failure, exacerbation } \\
\text { of psychotic } \\
\text { conditions }\end{array}$ & \\
\hline $\begin{array}{l}\text { Carbidopa- } \\
\text { levodopa }\end{array}$ & No & $\mathrm{N} / \mathrm{A}$ & Dopamine agonist & Parkinsonism & $\begin{array}{l}\text { Arousal from coma } \\
\text { or minimally } \\
\text { conscious states }\end{array}$ & & \\
\hline Bromocriptine & Yes, ages 11-18 y & $1.25-2.5 \mathrm{mg} / \mathrm{d}$ & Dopamine agonist & $\begin{array}{l}\text { Hyperprolactinemia- } \\
\text { associated disorders, } \\
\text { acromegaly, } \\
\text { parkinsonism }\end{array}$ & $\begin{array}{l}\text { Arousal from coma } \\
\text { or minimally } \\
\text { conscious states }\end{array}$ & $\begin{array}{l}\text { Cardiovascular } \\
\text { adverse effects, } \\
\text { hypotension, peptic } \\
\text { ulcers }\end{array}$ & \\
\hline Methylphenidate & $\begin{array}{l}\text { Yes, } 6 \text { y and } \\
\text { older }\end{array}$ & $\begin{array}{l}\text { Start at } 5 \mathrm{mg} \text { QD, may } \\
\text { increase to BID, } \\
\text { maximum dose } 60 \mathrm{mg} \\
\text { daily }\end{array}$ & $\begin{array}{l}\text { Catecholamine } \\
\text { agonist }\end{array}$ & $\begin{array}{l}\text { Attention deficit } \\
\text { disorder, narcolepsy }\end{array}$ & $\begin{array}{l}\text { Attentional deficits; } \\
\text { arousal from } \\
\text { coma or } \\
\text { minimally } \\
\text { conscious states }\end{array}$ & $\begin{array}{l}\text { Cardiovascular } \\
\text { adverse effects, } \\
\text { growth impairment }\end{array}$ & Dependence \\
\hline Amphetamine & $\begin{array}{l}\text { Yes, } 6 \text { y and } \\
\text { older }\end{array}$ & $\begin{array}{l}\text { Start at } 5 \mathrm{mg} Q \mathrm{QD} \text {, may } \\
\text { increase to BID, } \\
\text { maximum dose } 40 \mathrm{mg} \\
\text { daily }\end{array}$ & $\begin{array}{l}\text { Catecholamine } \\
\text { agonist }\end{array}$ & $\begin{array}{l}\text { Attention deficit } \\
\text { disorder, narcolepsy }\end{array}$ & $\begin{array}{l}\text { Attentional deficits; } \\
\text { arousal from } \\
\text { coma or } \\
\text { minimally } \\
\text { conscious states }\end{array}$ & & \\
\hline Propranolol & No & N/A & $\begin{array}{l}\beta \text {-Adrenergic } \\
\text { receptor blocker }\end{array}$ & $\begin{array}{l}\text { HTN, angina, A-fib, Ml, } \\
\text { migraine, essential } \\
\text { tremor, headache }\end{array}$ & Agitation & $\begin{array}{l}\text { Diabetes, } \\
\text { thyrotoxicosis }\end{array}$ & $\begin{array}{l}\text { Angina } \\
\text { pectoris }\end{array}$ \\
\hline
\end{tabular}

$\mathrm{N} / \mathrm{A}=$ not applicable; $\mathrm{A}$-fib $=$ atrial fibrillation; HTN = hypertension;Ml = myocardial infarction; FDA = Food and Drug Administration; NMDA = $\mathrm{N}$-methyl-D-aspartate; $\mathrm{TBI}=$ traumatic brain injury; $\mathrm{QD}=$ once a day; $\mathrm{BID}=$ twice a day.

topiramate could offer neuroprotection after TBI, more human data are required.

\section{IMPAIRED AROUSAL}

One of the best indicators for predicting outcome from severe TBI is duration of coma or vegetative state, with worse long-term outcomes seen in patients with longer periods of unconsciousness [24]. It is presumed that reducing the pe- riod of unconsciousness will improve long-term outcome. Earlier arousal does enable earlier implementation of rehabilitation interventions and may reduce secondary complications from immobility.

\section{Dopamine Agonists}

Dopamine agonists are commonly used to improve arousal in patients who are comatose after TBI. These agents include

Table 3. NMDA antagonists

\begin{tabular}{|c|c|c|c|c|c|c|}
\hline Medication & $\begin{array}{c}\text { FDA Approval in } \\
\text { Pediatric } \\
\text { Patients }\end{array}$ & FDA Pediatric Dosages & $\begin{array}{c}\text { Mechanism of } \\
\text { Action }\end{array}$ & $\begin{array}{c}\text { FDA } \\
\text { Indications }\end{array}$ & TBI Usage & Serious Reactions \\
\hline Amantadine & $\begin{array}{l}\text { Yes, > } 1 \text { y of age } \\
\text { (influenza only) }\end{array}$ & $\begin{array}{l}\text { Ages 1-9 y: } 2.2-4.4 \mathrm{mg} / \\
\text { kg BID, up to } 75 \mathrm{mg} \\
\text { BID, >9 y } 100 \mathrm{mg} \mathrm{BID,} \\
\text { typically start at } 1 / 2 \\
\text { lowest dose, titrate to } \\
\text { maximum }\end{array}$ & $\begin{array}{l}\text { Dopamine } \\
\text { agonist, } \\
\text { NMDA } \\
\text { antagonist }\end{array}$ & $\begin{array}{l}\text { Influenza A, } \\
\text { parkinsonism, } \\
\text { extrapyramidal } \\
\text { reactions }\end{array}$ & $\begin{array}{l}\text { Arousal from } \\
\text { coma or } \\
\text { minimally } \\
\text { conscious } \\
\text { states }\end{array}$ & $\begin{array}{l}\text { Neuroleptic malignant } \\
\text { syndrome with } \\
\text { abrupt withdrawal, } \\
\text { exacerbation of } \\
\text { congestive heart } \\
\text { failure, exacerbation } \\
\text { of psychotic } \\
\text { conditions }\end{array}$ \\
\hline Ketamine & Yes & $\mathrm{N} / \mathrm{A}$ & $\begin{array}{l}\text { NMDA } \\
\text { antagonist }\end{array}$ & $\begin{array}{l}\text { Procedural } \\
\text { sedation }\end{array}$ & $\begin{array}{l}\text { Neuroprotective } \\
\text { agent }\end{array}$ & Respiratory depression \\
\hline Memantine & No & N/A & $\begin{array}{l}\text { NMDA } \\
\text { antagonist }\end{array}$ & $\begin{array}{l}\text { Alzheimer } \\
\text { dementia }\end{array}$ & $\begin{array}{l}\text { Neuroprotective } \\
\text { agent, } \\
\text { memory }\end{array}$ & Seizures \\
\hline
\end{tabular}

$\mathrm{N} / \mathrm{A}=$ not applicable; FDA $=$ Food and Drug Administration; NMDA $=\mathrm{N}$-methyl-D-aspartate. 
carbidopa-levodopa, amantadine, bromocriptine, pramipexole, methylphenidate, amphetamine, and apomorphine [25] (Table 2). In addition to the weak NMDA-antagonistic qualities, amantadine affects dopamine both presynapse by stimulating its release and delaying its reuptake, and postsynapse by increasing the number of dopamine receptors [26]. In the pediatric population, amantadine is the most well studied of the dopamine agonists for treating arousal, although only 4 studies are available [27-30]. As such, these studies will be described in detail, both to indicate efficacy of amantadine and to point out areas of need within this literature. Green et al [27] reported the results of a case-controlled chart review of 102 patients, 46 of whom had been treated with amantadine. The investigators found a small but statistically significant improvement in Rancho Los Amigos Scale (RLA) level in patients treated with amantadine. No differences were observed, however, in length-of-stay or duration of post-traumatic amnesia. It is important to note that this was an unblinded, retrospective study, which raises concerns about possible clinician bias.

Patrick et al [30] also performed a retrospective study of 10 children who were previously enrolled in clinical protocols following TBI and resulting low response state. It should be noted that children in this study may have been treated with 1 to 2 of 4 different dopamine agonists, with just 3 patients treated with amantadine and only 1 treated solely with amantadine. The Western NeuroSensory Stimulation Profile was used to assess cognitive change, with change in slope attributed to efficacy of the intervention. In the single subject treated only with amantadine, the slope worsened, whereas in the 2 subjects treated with amantadine and another agonist (bromocriptine or pramipexole), 1 showed an improved slope and 1 worsened. This study does not provide sufficient evidence to support the use of amantadine in pediatric TBI and may in fact suggest a detrimental effect.

In a second report by this group $[29,30]$, amantadine was compared with pramipexole in 6 children and 4 young adults. (The investigators reported subjects as 10 pediatric patients, but 3 subjects were 19 years, and 1 was 21 years old.) A randomized control, prospective study without a placebo group design was used. Although the investigators described this as a double-blind trial, they were aware that the subjects were on a presumed stimulant, so they were truly not blinded raters. Measurements were taken during the week before starting the dopamine agonist, during a 4-week dose-ramping period, over the course of a 3-week weaning period, and finally postmedication. Four subjects were randomized to amantadine, with 3 of the subjects at 40-47 days postinjury and the fourth subject at 232 days postinjury. Not surprisingly, there was no change in the subject who was 232 days postinjury. Among the other 3, 1 remained at an RLA score of II, 1 improved from RLA III to IV, and the third improved from RLA II to VI. With such a small number of subjects and the wide variability in the natural recovery from
TBI not accounted for by a placebo group, these data do not adequately demonstrate benefit from amantadine. Inclusion of the 4 young adults in the sample further detracts from our ability to ascertain what the results mean for pediatric patients.

Recently, McMahon et al [28] published a randomized, double-blind, placebo-controlled cross-over trial of amantadine. The subjects were treated with either amantadine or placebo for 2 weeks, given a 1-week washout, and then were crossed over to the other treatment for 2 weeks. Five subjects completed the protocol, although only 3 had sustained TBI, and 1 of those was not pediatric, at 18 years of age. Of the remaining 2 subjects, 1 was in each arm of the protocol. The subject in the placebo-first arm remained in a vegetative state throughout the study. The other subject moved from minimally conscious to fully conscious.

These 2 studies by Patrick et al $[29,30]$ include the only available data regarding use of pramipexole to improve arousal in pediatric patients with TBI. In their retrospective study [30], the 2 subjects treated only with pramipexole did show improvements in the slope of their Western NeuroSensory Stimulation Profile. The third subject was treated with amantadine and showed a decline in slope. In the prospective trial, 2 subjects were treated with pramipexole, and both remained at their baseline RLA of II [29]. As with amantadine, with no placebo group and such small number of subjects, it was not possible to attribute any recovery (or lack of recovery) to pramipexole.

We found only 1 article that provided data on bromocriptine in pediatric TBI [31]. Of the 5 children with TBI treated with bromocriptine while in a vegetative state, 3 subjects were 16 years old. All of the subjects "regained functional status," although 2 required continued supervision. These results were noted to be more than would be expected due to chance or recovery alone. Among the reviewed dopamine agonists, bromocriptine has the least desirable adverse effect profile, so it is not a preferred first-line agent.

Research on methylphenidate for arousal in pediatric TBI is also very limited. In a small sample retrospective review, Hornyak et al [32] noted improvements in the mental status of 2 patients after starting methylphenidate while they were in a minimally conscious state. Because this study was not blinded or controlled in any manner, it cannot provide conclusive evidence to support the use of methylphenidate in the early stages of recovery from severe TBI. The strongest evidence that supports methylphenidate for improving arousal comes from the retrospective review by Patrick et al $[29,30]$. In that study, all 4 subjects treated with methylphenidate showed a positive change in the slope of their recovery based upon Western NeuroSensory Stimulation Profile scores.

\section{$\gamma$-Aminobutyric Acid Agonists}

Beyond dopamine agonists, a few other pharmacologic agents have been reported to improve arousal after TBI. 
Table 4. GABA agonists

\begin{tabular}{|c|c|c|c|c|c|c|c|}
\hline Medication & $\begin{array}{l}\text { FDA Approval } \\
\text { in Pediatric } \\
\text { Patients }\end{array}$ & FDA Pediatric Dosages & $\begin{array}{l}\text { Mechanism } \\
\text { of Action }\end{array}$ & FDA Indications & $\begin{array}{c}\text { TBI } \\
\text { Usage }\end{array}$ & Serious Reactions & Warnings \\
\hline Baclofen & $\begin{array}{l}\text { Yes, } 12 \text { y and } \\
\text { older }\end{array}$ & $\begin{array}{l}\text { Oral: start } 5 \text { mg TID, gradually } \\
\text { titrate to maximum } 60 \text { mg/ } \\
\text { d; intrathecal patient } \\
\text { dependent }\end{array}$ & $\begin{array}{l}\text { GABA-B } \\
\text { agonist }\end{array}$ & Spasticity & Spasticity & $\begin{array}{l}\text { Seizures, death with } \\
\text { abrupt withdrawal }\end{array}$ & \\
\hline Midazolam & Yes & Age and weight based & $\begin{array}{l}\text { Facilitation of } \\
\text { the GABA }\end{array}$ & $\begin{array}{l}\text { Sedation, } \\
\text { anesthesia } \\
\text { induction }\end{array}$ & $\begin{array}{l}\text { Acute } \\
\text { agitation }\end{array}$ & $\begin{array}{l}\text { Respiratory arrest, } \\
\text { cardiac arrest }\end{array}$ & $\begin{array}{l}\text { Respiratory } \\
\text { depression }\end{array}$ \\
\hline Alprazolam & No & $0.25-3 \mathrm{mg}$ & $\begin{array}{l}\text { Facilitation of } \\
\text { the GABA }\end{array}$ & $\begin{array}{l}\text { Anxiety, panic } \\
\text { disorder }\end{array}$ & $\begin{array}{l}\text { Agitation, } \\
\text { anxiety }\end{array}$ & $\begin{array}{l}\text { Syncope, tachycardia, } \\
\text { seizures, respiratory } \\
\text { depression }\end{array}$ & Dependence \\
\hline Lorazepam & Yes & $0.05 \mathrm{mg} / \mathrm{kg}$ & $\begin{array}{l}\text { Facilitation of } \\
\text { the GABA }\end{array}$ & $\begin{array}{l}\text { Anxiety, } \\
\text { insomnia, status } \\
\text { epilepticus }\end{array}$ & Agitation & $\begin{array}{l}\text { Respiratory depression, } \\
\text { seizures, depression }\end{array}$ & Dependence \\
\hline Diazepam & $\begin{array}{l}\text { Safety in age } \\
<6 \text { mo not } \\
\text { established }\end{array}$ & $2-10 \mathrm{mg}$ & $\begin{array}{l}\text { Facilitation of } \\
\text { the GABA }\end{array}$ & $\begin{array}{l}\text { Anxiety, } \\
\text { preoperative } \\
\text { sedation, EtOH } \\
\text { withdrawal, } \\
\text { seizure disorder }\end{array}$ & Agitation & $\begin{array}{l}\text { Respiratory depression, } \\
\text { seizures, depression }\end{array}$ & \\
\hline Clonazepam & $\begin{array}{l}\text { age }>10 \text { y or } \\
>30 \mathrm{~kg} \\
\text { weight }\end{array}$ & $\begin{array}{c}0.01-0.03 \mathrm{mg} / \mathrm{kg} / \mathrm{d}, \text { not to } \\
\text { exceed } 0.05 \mathrm{mg} / \mathrm{kg} / \mathrm{d}\end{array}$ & $\begin{array}{l}\text { Facilitation of } \\
\text { the GABA }\end{array}$ & $\begin{array}{l}\text { Seizure disorder, } \\
\text { panic disorder }\end{array}$ & Agitation & $\begin{array}{l}\text { Respiratory depression, } \\
\text { seizures, depression }\end{array}$ & Hepatotoxicity \\
\hline
\end{tabular}

$\mathrm{EtOH}=$ ethanol; FDA = Food and Drug Administration; GABA $=\gamma$-aminobutyric acid; $\mathrm{TBI}=$ traumatic brain injury.

Zolpidem is an omega 1-specific, indirect $\gamma$-aminobutyric acid (GABA) agonist used in treating insomnia. After TBI, GABA may produce a paradoxical effect, thereby stimulating a certain subset of patients at lower levels of consciousness (eg, coma, vegetative state, or minimally conscious state) (Table 4). In the adult literature, several case reports have appeared that suggest possible benefit in using this agent in patients with disorders of consciousness after a TBI. Clauss et al [33] described an adult man who, 15 minutes after administration of zolpidem, awoke from a semicomatose state and remained awake for the next 3-4 hours. Brain single-photonemission computed tomography after drug administration showed generalized cortical activation and amplified activation of the areas that were hypoactive before drug application. Clauss and Nel [34] later reported on 3 adult patients who were in a vegetative state for at least 3 years after brain injury. Transient arousal was apparent every morning after zolpidem administration. In addition, even after 3-6 years of daily use, drug efficacy did not decline, nor were long-term adverse effects observed. Cohen and Duong [35] described a 35 -year-old man who sustained an anoxic brain injury because of cardiac arrest, with subsequent extreme lethargy and lack of response to stimuli, which persisted despite trials of several medications. Zolpidem given twice daily 8 months after injury resulted in a dramatic increase in the patient's level of alertness. The effect was lost when Zolpidem was discontinued and returned when the medication was resumed. Whyte and Myers [36] compared zolpidem with placebo in 15 adults with TBI by using a double-blind crossover design. One participant demonstrated a clinically signif- icant response, progressing from a vegetative state to a minimally conscious state, whereas the remaining 14 participants showed no evidence of response to the drug. Clearly, additional studies are needed regarding the possible roles that zolpidem and other agents may play in treating disorders of consciousness after TBI. At present, it is unclear which subset of patients would benefit, what the ideal dose and frequency of administration would be, or the long-term efficacy and potential long-term adverse effects of medication therapy. Furthermore, research is needed to determine whether these findings can be safely generalized to pediatric populations.

Intrathecal Baclofen. Recently, several case reports described dramatic improvement in patients in vegetative states after intrathecal baclofen (ITB) administration [37-40]. One case report [37] described an 11-year-old girl who sustained a severe TBI. Eighteen days after her injury, she was given a trial of $100 \mu \mathrm{g}$ ITB while she was under general anesthesia. Within 2 days, dramatic improvements in mental status were observed. Although this case is interesting and warrants further investigation, it is important to acknowledge that ITB has frequently been used for spasticity management, but there have been no other reports of dramatic improvements in cognitive status.

\section{AGITATION}

Agitation remains a challenging issue for patients after TBI. It likely reduces the efficacy of acute rehabilitation [41]. Debate continues about how to define and characterize post-TBI 
agitation. A survey by Fugate et al [42] showed that physical aggression, verbal aggression, and explosive anger were characteristics associated with agitation. Moreover, the majority of physicians associate agitation with aggression. Mysiw et al [43] defined agitation as the "subjective evidence of one or more of the following behaviors: restlessness, derogatory or threatening demands, verbal abusiveness, sexually inappropriate comments or actions, or attempts at physical violence of sufficient severity to disrupt nursing care or therapy." In treating agitation, clinicians must first determine its cause or at least minimize factors that may contribute to or exacerbate agitation. For example, drug and alcohol withdrawal, pain, dementia, endocrine dysfunction, or seizures may mimic or exacerbate agitation in this population. Catheters and intravenous leads should be discontinued as soon as medically appropriate. Noise (especially during the hours of sleep) should be kept at minimum. Visitors should be limited. Therapies should be evenly spaced throughout the day, preferably with down time between periods of therapy.

Many medications of varying mechanisms have been used to manage post-TBI agitation. However, there are no wellcontrolled studies to evaluate which treatment is the most effective $[44,45]$ in either the adult or the pediatric population. With the wide range of pharmacologic agents available, clinicians must consider each patient individually, weighing the level of agitation, potential adverse effects of a given medication, patient comorbidities and medical history, speed of onset of medication effects, and route of medication delivery.

\section{Benzodiazepines}

Benzodiazepines provide anxiolytic, sedative, antispasticity, anticonvulsant, and amnestic effects. Most of these effects are thought to result from facilitation of the action of GABA, an inhibitory neurotransmitter in the central nervous system. Benzodiazepines are commonly used in patients after TBI [46]. The benzodiazepines are loosely divided into 3 categories: short acting (half-life of 1-8 hours), intermediate acting (half-life of 8-40 hours), and long acting (half-life longer than 40 hours). Short-acting benzodiazepines are commonly used in acute settings, such as during induction of minor surgical procedures (eg, midazolam) or in treating acute anxiety (eg, alprazolam). Wroblewski and Joseph [47] reported 10 cases (9 adults and 19 -year-old boy with anoxic brain injury) in which intramuscular midazolam was used to treat acute seizures or behavioral problems in patients with brain injury. They found effective treatment of these conditions without significant adverse effects. Alprazolam is not widely used in treating post-TBI agitation. Rather, intermediate-acting (eg, lorazepam) and long-acting benzodiazepines (eg, diazepam and clonazepam) are much more commonly prescribed for this purpose.

Long-term use of benzodiazepines is not free of risk. This class of medication may have both short-term and long-term implications for recovery in children with TBI. Acutely, benzodiazepines may contribute to daytime fatigue, decreased concentration, decreased alertness, and memory loss [48]. To further add to the complexity, these adverse effects are common sequelae of TBI and are frequently present independent of the medication. Repeated use of benzodiazepines may ultimately slow and/or impair neuronal recovery after neurologic injury [46,49]. Goldstein [49] reported that, in animal models, benzodiazepines may impair recovery of function after focal brain damage. Hence, this class of medication should not be considered a viable option for long-term treatment and should be used sparingly. Pediatric-specific studies are needed to determine the efficacy of managing post-TBI agitation, dosing strategies, and the impact on ultimate recovery of pediatric patients after TBI. No large clinical trials of children with TBI treated with GABA agonists are reported.

\section{$\beta$-Blockers}

This class of medication is most commonly used in the treatment of hypertension and has been shown to be useful in treating migraine headaches, akathisia, and anxiety. $\beta$-Blockers are commonly used in the TBI population for hyperadrenergic activity [50] while simultaneously treating post-TBI agitation. The literature best supports $\beta$-blockers for postTBI agitation in adults [44]. Propranolol is a nonselective $\beta$-blocker, which inhibits both $\beta_{1}$ - and $\beta_{2}$-adrenergic receptors. It is relatively short acting and lipophilic, and is likely the most frequently used and well-studied medication in this class [51]. Brooke et al [51] followed up 21 adults with traumatic closed head injury and post-TBI agitation treated at a combined level I trauma center and rehabilitation center. Subjects were treated with either propranolol or placebo in a double-blinded fashion. The intensity of agitation was found to be significantly lower in the treatment group. In addition, the use of restraints was significantly lower in the treatment group. Brooke et al [51] concluded that propranolol was effective in reducing the intensity of agitation during initial hospitalization after closed head injury. It is important to note that patients treated with $\beta$-blockers need to be monitored for bradycardia, orthostatic hypotension, and fatigue. In general, dosage is determined by effect on agitation and presence of adverse effects. However, it should be noted that propranolol does not have a U.S. Food and Drug Administration (FDA) indication for children.

\section{Anticonvulsants}

In addition to managing seizures, anticonvulsants have been widely used to treat post-TBI agitation. Although the precise mechanism of action is unclear, many anticonvulsants decrease the levels or actions of excitatory neurotransmitters and/or enhance the levels or actions of inhibitory neurotransmitters. These properties may be responsible for actions of 
these medications as central nervous system depressants. Although these agents have been shown to effectively manage agitation, they are also known to exert potentially adverse effects on cognitive and motor functions in patients with epilepsy [22,52], and there is no reason to assume that they would not have similar negative effects in a pediatric TBI population. For example, levetiracetam can be associated with psychosis in children treated for epilepsy [53], whereas topiramate may dampen cognitive functioning [54].

Chatham Showalter [55] performed a retrospective chart review of all patients who received valproic acid for agitation symptoms during a 22-month period at 2 inpatient TBI rehabilitation units. The subjects were between 13 and 89 years old. In 26 patients (90\% of the study population), valproic acid was effective in reducing agitation symptoms within 7 days when using a typical dose of $1250 \mathrm{mg} / \mathrm{d}$. Change in agitation was based upon both the Agitation Behavioral Scale (8 subjects) and behaviors documented in the clinical progress notes. The investigators concluded that valproic acid appears to be an efficacious alternative to neuroleptics and benzodiazepines for alert, labile, impulsive, and disinhibited patients after TBI. Wroblewski et al [56] reported on the efficacy of valproic acid in reducing and improving destructive and aggressive behaviors in 5 adults with acquired brain injury. In all cases, valproic acid was effective after other pharmacologic interventions proved ineffective.

We found no published studies regarding the safety and efficacy of carbamazepine (Table 5) in pediatric patients with TBI. Chatham-Showalter [57] reported the use of carbamazepine with 7 combative adult patients with multiple traumas, including TBI. The study participants demonstrated a clinical decrease in combativeness within 4 days after beginning carbamazepine compared with the trauma center's experience of prolonged combative periods without its use. Azouvi et al [58] followed up 10 adults with agitation and anger after severe closed head injury. They performed an 8-week, prospective open trial of carbamazepine, with doses that ranged from 400 to $800 \mathrm{mg}$ a day. They found a significant improvement in patient scores on the Agitated Behavior Scale. Social functioning also improved significantly. The investigators concluded that carbamazepine might help to reduce agitated behavior in patients after brain injury.

In a single case report, Pachet et al [59] reported the effectiveness of lamotrigine in treating aggressive and agitated behavior in a 40-year-old man who had sustained a severe TBI. A substantial decrease in problematic behaviors and a significant improvement in neurobehavioral functioning was found after lamotrigine was initiated. These investigators suggest that lamotrigine may be useful in treating aggression and agitation in patients with TBI. There are no published data regarding the use of lamotrigine to treat agitation in children with TBI.

Anticonvulsants are used extensively in children for the treatment of epilepsy, and, in most cases, information about the general safety and risks of these medications in pediatric populations is available. However, additional studies are needed to determine whether anticonvulsant medications may be safely and effectively used in treating agitation after pediatric TBI (with or without epilepsy). Currently, data are lacking regarding the efficacy, appropriate dosing strategies, and impact of anticonvulsant medications on ultimate recovery after TBI in childhood.

\section{Antidepressants}

Selective serotonin reuptake inhibitors (SSRIs) are the mainstay in the treatment of primary depression [60]. Due to their greater efficacy and tolerability, they have largely replaced tricyclic antidepressants (TCAs) for depression (Table 6).

Table 5. Antiepileptics

\begin{tabular}{|c|c|c|c|c|c|c|c|}
\hline Medication & $\begin{array}{l}\text { FDA Approval in } \\
\text { Pediatric } \\
\text { Patients }\end{array}$ & $\begin{array}{l}\text { FDA Pediatric } \\
\text { Dosages }\end{array}$ & Mechanism of Action & FDA Indications & TBI Usage & $\begin{array}{l}\text { Serious } \\
\text { Reactions }\end{array}$ & Warnings \\
\hline Divalproex & $\begin{array}{l}\text { Yes, children }>10 \\
\text { y old }\end{array}$ & $\begin{array}{l}\text { Initial dosage } \\
\text { 10-15 mg/ } \\
\text { kg/d }\end{array}$ & $\begin{array}{l}\text { Suggested to increase } \\
\text { brain concentrations } \\
\text { of GABA }\end{array}$ & $\begin{array}{l}\text { Mania, epilepsy, } \\
\text { migraine }\end{array}$ & $\begin{array}{l}\text { Agitation, } \\
\text { headache }\end{array}$ & $\begin{array}{l}\text { Teratogenicity, } \\
\text { pancreatitis }\end{array}$ & Hepatotoxicity \\
\hline Valproic acid & $\begin{array}{l}\text { Yes, children > } 10 \\
\text { y old }\end{array}$ & $\begin{array}{l}\text { Initial dosage } \\
\text { 10-15 mg/ } \\
\text { kg/d }\end{array}$ & $\begin{array}{l}\text { Suggested to increase } \\
\text { brain concentrations } \\
\text { of GABA }\end{array}$ & $\begin{array}{l}\text { Seizure, mania, } \\
\text { migraine HA }\end{array}$ & Agitation & $\begin{array}{l}\text { Teratogenicity, } \\
\text { pancreatitis }\end{array}$ & Hepatotoxicity \\
\hline Carbamazepine & $\begin{array}{l}\text { Yes, children > }>12 \\
\text { y old }\end{array}$ & Age based & $\begin{array}{l}\text { Suggested to increase } \\
\text { GABA }\end{array}$ & $\begin{array}{l}\text { Bipolar disorder, } \\
\text { epilepsy, } \\
\text { trigeminal } \\
\text { neuralgia }\end{array}$ & $\begin{array}{l}\text { Agitation, } \\
\text { chronic } \\
\text { headache }\end{array}$ & $\begin{array}{l}\text { Aplastic anemia, } \\
\text { agranulocytosis }\end{array}$ & $\begin{array}{l}\text { Toxic } \\
\text { epidermal } \\
\text { necrolysis } \\
\text { and Stevens- } \\
\text { Johnson } \\
\text { syndrome }\end{array}$ \\
\hline Lamotrigine & $\begin{array}{l}\text { Yes, patients } \\
\geq 2 \text { y old }\end{array}$ & $\begin{array}{l}\text { Age and } \\
\text { weight } \\
\text { based }\end{array}$ & Unknown & $\begin{array}{l}\text { Seizure, bipolar } \\
\text { disorder, }\end{array}$ & Agitation & & \\
\hline
\end{tabular}

$\mathrm{FDA}=$ Food and Drug Administration; GABA $=\gamma$-aminobutyric acid; $\mathrm{TBI}=$ traumatic brain injury. 
Table 6. Antidepressants

\begin{tabular}{|c|c|c|c|c|c|c|c|}
\hline Medication & $\begin{array}{c}\text { FDA } \\
\text { Approval in } \\
\text { Pediatric } \\
\text { Patients }\end{array}$ & $\begin{array}{c}\text { FDA Pediatric } \\
\text { Dosages }\end{array}$ & Mechanism of Action & FDA Indications & TBI Usage & Serious Reactions & Warnings \\
\hline Amitriptyline & $\begin{array}{l}\text { Yes, children } \\
>12 \text { y old }\end{array}$ & $10 \mathrm{mg}$ & $\begin{array}{l}\text { Inhibits norepinephrine } \\
\text { and serotonin } \\
\text { reuptake }\end{array}$ & Depression & $\begin{array}{l}\text { Depression, agitation, } \\
\text { chronic pain }\end{array}$ & $\begin{array}{l}\text { Ventricular arrhythmias, } \\
\text { torsades de pointes }\end{array}$ & Suicidality \\
\hline Sertraline & Yes & $\begin{array}{l}\text { Maximum of } \\
200 \mathrm{mg} / \mathrm{d}\end{array}$ & $\begin{array}{l}\text { Selective serotonin } \\
\text { reuptake inhibitor }\end{array}$ & $\begin{array}{l}\text { Depression, OCD, } \\
\text { panic disorder, } \\
\text { PTSD, PMDD }\end{array}$ & Depression, agitation & $\begin{array}{l}\text { Neuroleptic malignant } \\
\text { syndrome, serotonin } \\
\text { syndrome }\end{array}$ & Suicidality \\
\hline Citalopram & Yes & $\begin{array}{l}\text { Maximum } 40 \\
\text { mg/d }\end{array}$ & $\begin{array}{l}\text { Selective serotonin } \\
\text { reuptake inhibitor }\end{array}$ & Depression & $\begin{array}{l}\text { Depression, agitation, } \\
\text { anxiety, OCD, } \\
\text { stuttering }\end{array}$ & $\begin{array}{l}\text { Neuroleptic malignant } \\
\text { syndrome, serotonin } \\
\text { syndrome }\end{array}$ & Suicidality \\
\hline Paroxetine & No & N/A & $\begin{array}{l}\text { Serotonin reuptake } \\
\text { inhibitor }\end{array}$ & $\begin{array}{l}\text { Depression, OCD, } \\
\text { panic disorder, } \\
\text { PTSD, GAD }\end{array}$ & Depression, agitation & $\begin{array}{l}\text { Neuroleptic malignant } \\
\text { syndrome, serotonin } \\
\text { syndrome }\end{array}$ & Suicidality \\
\hline Fluoxetine & No & N/A & $\begin{array}{l}\text { Inhibition of CNS } \\
\text { neuronal uptake of } \\
\text { serotonin }\end{array}$ & PMDD & Depression, agitation & $\begin{array}{l}\text { Neuroleptic malignant } \\
\text { syndrome, serotonin } \\
\text { syndrome }\end{array}$ & Suicidality \\
\hline
\end{tabular}

$\mathrm{N} / \mathrm{A}=$ not applicable; $\mathrm{OCD}=$ obsessive compulsive disorder; PTSD = post-traumatic stress disorder; PMDD = premenstrual dysphoric disorder; GAD = generalized anxiety disorder; CNS = central nervous system; FDA = Food and Drug Administration.

However, TCAs still play a role in physiatric care of adult patients with TBI [61] and of adults with chronic or neuropathic pain. TCAs, including amitriptyline, have been shown in limited reports to be effective in managing post-TBI agitation $[43,62,63]$ in adults. The adverse effect profile of this class of medication may limit its use with children. Also, most of the TCAs are not approved by the FDA for young children with depression.

The SSRI sertraline has been shown to be effective in treating depression after TBI [64-68] and may have an additional role in treating post-TBI agitation [68-70]. Fann et al [68] reported on an 8-week, nonrandomized, single-blind, placebo, run-in trial of sertraline in 15 adults diagnosed with major depression and mild TBI. By week 8 of treatment with sertraline, $87 \%$ of the participants showed a $50 \%$ reduction in their depression, and $67 \%$ of the participants achieved a depression measure score with the normative range. Similarly, Kant et al [69] followed up 13 adults who experienced problems with irritability and aggression after TBI. A significant reduction in irritability and aggressive outbursts was observed during the course of a nonblinded, 8-week, open trial of sertraline. Other SSRIs, including citalopram, paroxetine, and fluoxetine, may prove useful, but data are limited [71-73].

There are few reports that discuss the effectiveness of SSRIs in the pediatric TBI population. Furthermore, the FDA adopted a "black box" label warning that indicates that antidepressants may increase the risk of suicidal thinking and behavior in some children and adolescents with major depression. Clinicians and parents or caregivers should closely monitor children and adolescents taking SSRIs for any worsening in depression, emergence of suicidal thinking or behavior, or unusual changes in behavior, such as sleeplessness, agitation, or withdrawal from normal social situations.
The FDA recommends very close monitoring, especially during the first 4 weeks of treatment. Additional studies in the pediatric population are needed.

\section{Antipsychotics}

Traditionally, antipsychotic agents have been used to treat psychosis and schizophrenia; however, their use has expanded to include treatment of agitation after TBI (Table 7). Unfortunately, a number of adult studies have documented either slowed cognitive improvement or reduced cognitive return [43,74-77] with the use of antipsychotic agents. Firstgeneration (or typical) antipsychotics act by blocking the $\mathrm{D}_{2}$ dopamine receptor. Atypical antipsychotic agents (AAPs) are believed to have much less effect on the $\mathrm{D}_{2}$ dopamine receptor. As a result, they are believed to have fewer adverse effects and less effect on TBI recovery [78]. AAPs likely act on other neurotransmitter pathways, including serotonin, dopamine, $\alpha_{1}$-adrenergic, muscarinic, and histamine pathways $[79,80]$. This class of medication includes clozapine, risperidone, quetiapine, ziprasidone, and olanzapine. Adverse effects of the antipsychotic medications include weight gain, extrapyramidal symptoms (EPSs), akathisia, and neuroleptic malignant syndrome (NMS). Both typical and AAP agents are associated with weight gain, with clozapine appearing to have the greatest and ziprasidone having the least effect on weight [81]. EPSs are common with typical antipsychotics and are occasionally encountered at higher doses of the AAPs. Akathisia, a subjective sense of restlessness often accompanied by involuntary movements of the limbs or trunk, is among the more common movement disorders associated with antipsychotic medications. Long-term use of antipsychotics is also associated with tardive dyskinesia, the late onset of choreoathetotic or other abnormal repetitive, invol- 
Table 7. Antipsychotics

\begin{tabular}{|c|c|c|c|c|c|c|c|}
\hline Medication & $\begin{array}{c}\text { FDA Approval } \\
\text { in Pediatric } \\
\text { Patients }\end{array}$ & $\begin{array}{c}\text { FDA Pediatric } \\
\text { Dosages }\end{array}$ & $\begin{array}{c}\text { Mechanism of } \\
\text { Action }\end{array}$ & FDA Indications & $\begin{array}{c}\text { TBI } \\
\text { Usage }\end{array}$ & Serious Reactions & Warnings \\
\hline Clozapine & No & $\mathrm{N} / \mathrm{A}$ & $\begin{array}{l}\text { D1, D2, D3, D4, D5 } \\
\text { receptor } \\
\text { antagonism }\end{array}$ & $\begin{array}{l}\text { Recurrent suicidal } \\
\text { behavior, } \\
\text { treatment-resistant } \\
\text { schizophrenia }\end{array}$ & Agitation & $\begin{array}{l}\text { Seizures, myocarditis, } \\
\text { orthostatic } \\
\text { hypotension }\end{array}$ & Agranulocytosis \\
\hline Risperidone & $\begin{array}{l}\text { Yes, 13-17 y of } \\
\text { age }\end{array}$ & $\begin{array}{l}\text { Initiated at } 0.5 \mathrm{mg} \\
\text { once daily, } \\
\text { titrate to a } \\
\text { recommended } \\
\text { dose of } 2.5 \mathrm{mg} / \mathrm{d}\end{array}$ & $\begin{array}{l}\text { D2 and serotonin } \\
\text { (5HT2) receptor } \\
\text { antagonism }\end{array}$ & $\begin{array}{l}\text { Schizophrenia, acute } \\
\text { manic, or mixed } \\
\text { episodes } \\
\text { associated with } \\
\text { bipolar I }\end{array}$ & Agitation & $\begin{array}{l}\text { Cognition and motor } \\
\text { impairment, } \\
\text { seizures }\end{array}$ & $\begin{array}{l}\text { Tardive } \\
\text { dyskinesia }\end{array}$ \\
\hline Quetiapine & $\begin{array}{l}\text { Yes, 10-17 y } \\
\text { old }\end{array}$ & $25-400 \mathrm{mg}$ & $\begin{array}{l}\text { D2 and serotonin } \\
\text { (5HT2) antagonism }\end{array}$ & $\begin{array}{l}\text { Schizophrenia, } \\
\text { bipolar mania }\end{array}$ & $\begin{array}{l}\text { Agitation, } \\
\text { insomnia }\end{array}$ & $\begin{array}{l}\text { NMS, tardive } \\
\text { dyskinesia }\end{array}$ & Suicidality \\
\hline Ziprasidone & No & $\mathrm{N} / \mathrm{A}$ & $\begin{array}{l}\text { D2 and serotonin } \\
\text { (5HT2) antagonism }\end{array}$ & $\begin{array}{l}\text { Schizophrenia, } \\
\text { bipolar mania }\end{array}$ & $\begin{array}{l}\text { Agitation, } \\
\text { insomnia }\end{array}$ & $\begin{array}{l}\text { Prolonged QT } \\
\text { interval, NMS } \\
\text { tardive dyskinesia }\end{array}$ & \\
\hline Olanzapine & $\begin{array}{l}\text { Yes, 13-17 y } \\
\text { old }\end{array}$ & $\begin{array}{l}\text { Start at } 2.5-5 \mathrm{mg} \\
\text { once daily; } \\
\text { target: } 10 \mathrm{mg} / \mathrm{d}\end{array}$ & $\begin{array}{l}\text { Dopamine and } \\
\text { serotonin (5HT2) } \\
\text { antagonism }\end{array}$ & $\begin{array}{l}\text { Schizophrenia, acute } \\
\text { manic or mixed } \\
\text { episodes } \\
\text { associated with } \\
\text { bipolar I }\end{array}$ & Agitation & $\begin{array}{l}\text { NMS, tardive } \\
\text { dyskinesia }\end{array}$ & Suicidality \\
\hline Haloperidol & No & $\mathrm{N} / \mathrm{A}$ & $\begin{array}{l}\text { Not been clearly } \\
\text { established }\end{array}$ & $\begin{array}{l}\text { Schizophrenia, vocal } \\
\text { utterances of } \\
\text { Tourette's Disorder }\end{array}$ & Agitation & $\begin{array}{l}\text { NMS, tardive } \\
\text { dyskinesia }\end{array}$ & Sudden death \\
\hline Droperidol & $\begin{array}{l}\text { Yes, children } \\
>2 \text { y old }\end{array}$ & $\begin{array}{l}\text { initial dose } 0.1 \mathrm{mg} / \\
\mathrm{kg}\end{array}$ & $\begin{array}{l}\text { Antagonism of } \\
\text { apomorphine (in } \\
\text { dogs) }\end{array}$ & Antiemetic & Agitation & $\begin{array}{l}\text { Prolonged QT } \\
\text { interval, NMS, } \\
\text { tardive dyskinesia }\end{array}$ & Sudden death \\
\hline
\end{tabular}

$\mathrm{D}=$ dopamine; FDA = Food and Drug Administration; NMS = neuroleptic malignant syndrome; $\mathrm{TBI}$ = traumatic brain injury.

untary movements. Perhaps the most concerning risk is the development of NMS [82]. Although uncommon, early recognition of this condition is critical [83]. NMS is associated with blocked dopamine transmission, and features include fever, rigidity, mental status changes, and autonomic instability. It has been seen with every class of antipsychotic drug, including the AAPs [84].

Routine use of typical antipsychotic agents has been shown to have long-term and detrimental effects after TBI. In particular, patients with TBI may be at greater risk for NMS than the general population after long-term use of antipsychotics such as haloperidol [85]. Because of its speed of onset and multiple options for delivery route, haloperidol has been widely used in treating psychiatric patients with acute agitation. Similarly, it has been commonly used to treat post-TBI agitation [61]. Haloperidol may be effective and relatively safe if used sparingly [75] in adults. However, haloperidol is not FDA approved for use with children, and no studies have investigated its efficacy or safety for pediatric patients with TBI. Droperidol (which does have FDA approval for nausea treatment in children more than 2 years old) has been shown to have utility for adults post-TBI [86]. No clinical studies have examined the safety or efficacy in children with posttraumatic agitation.

The earliest AAP, clozapine, was reported to be useful in treating post-TBI agitation in adults [87]. However, it is now seldom used because of the need to closely monitor complete blood counts for the risk of agranulocytosis and aplastic anemia. Furthermore, clozapine may lower the seizure threshold [78]. Finally, clozapine does not have FDA approval for use in children. Ziprasidone is available in both oral and intramuscular formulations and has been shown to have a better adverse effect profile in terms of weight gain, glucose intolerance, and EPS [88]. Noé et al [89] followed up 5 adult patients and found ziprasidone effective in controlling agitation during the post-traumatic amnesia period. This agent worked quickly to reduce agitation and showed good tolerability and safety, with no electrocardiographic changes or clinical adverse effects. Scott et al [90] studied the use of ziprasidone in a pediatric post-TBI population. Twenty pediatric TBI patients were followed up over an 18-month period. All of the study patients developed agitation and/or aggression and were treated with ziprasidone as the sole intervention. No adverse events were seen in any of the subjects. The researchers noted a significant reduction in the Riker Sedation-Agitation Scale in all pediatric age groups. These researchers concluded that ziprasidone appeared to be a safe and effective treatment in pediatric patients with closed head injuries who develop agitation and/or aggression in the immediate postinjury period.

Quetiapine may have similar utility as a treatment option [91,92]. It has a low incidence of EPS. Kim and Bijlani [91] performed a 6-week, open-label, flexible-dose pilot study of quetiapine for treatment of post-TBI aggression. They fol- 
lowed up 7 adults with TBI who were at least 3 months postinjury. Quetiapine at doses of 25-300 $\mathrm{mg}$ daily was found to be efficacious and well tolerated in reducing irritability and aggression that resulted from TBI. Oster et al [92] reported beneficial effects of quetiapine on post-traumatic mania, cognitive impairments, and functional disability in the subacute postinjury period. Similarly, Daniels and Felde [93] described 2 adults with mania associated with TBI and who responded to quetiapine. Quetiapine is FDA approved in children more than 10 years of age with schizophrenia and bipolar disorder. No studies that used quetiapine were found in the pediatric TBI literature.

Olanzapine has been shown to have fewer cognitive adverse effects and detrimental effects on cognitive recovery than haloperidol in an animal model [94]. However, it is associated with weight gain, diabetes mellitus, and hyperlipidemia [88], and there are no studies that reported its efficacy in treating post-TBI agitation.

The use of this class of medication, including both typical and AAPs, remains controversial for both adults and children. Despite an apparent decreased adverse effect profile and potentially smaller negative impact on recovery from TBI associated with the AAP agents, likely all members of this class have detrimental effects after long-term use $[46,48,74,75,77,87]$. Clearly, more comprehensive and long-term studies are needed to evaluate the efficacy and effect on recovery of the antipsychotic agents in the pediatric TBI population. If clinicians choose to try these agents, despite the lack of evidence and concern for detrimental effects in children, they should then use the smallest dosage possible, monitor carefully for negative responses, and continually evaluate the need for ongoing use.

\section{COGNITIVE IMPAIRMENTS}

Numerous cognitive impairments may follow pediatric TBI [95], including deficits in attention and memory. Stimulants such as methylphenidate and amphetamine derivatives are the mainstays of treatment of these cognitive sequelae. Their mechanism of action is through the upregulation of both dopamine and norepinephrine, primarily within the prefrontal cortex [96]. The first reported use of methylphenidate for cognitive impairments was by Gualtieri and Evans [97], who examined its use in 15 patients, 12-44 years of age, with severe TBI. No statistical differences were found in cognitive performance with the use of methylphenidate, but subjective improvements were described by patients and families. Hornyak et al [32] completed a chart review of 9 pediatric patients treated with methylphenidate after TBI. Improvements in cognitive and behavioral impairments were observed in 7 of the patients, based upon parent and clinician documentation. Some of the subjects demonstrated improvements in cognitive testing as evaluated by a neuropsychologist and/or speech and language pathologist. The following year, 2 studies were published with contrasting results. Williams et al [98] examined the effect of methylphenidate in 10 children with mild to severe TBI. When compared with placebo, no differences were noted in behavior, attention, memory, or processing speed. Mahalick et al [99] evaluated 14 pediatric subjects after 7 days of twice daily methylphenidate. Statistically significant results were found across all measures of attention and/or concentration. Thus, the research support for methylphenidate is equivocal but suggests a potential beneficial response, at least in some children recovering from or living with the sequelae of TBI. Further studies are clearly needed.

The nAch-r agonists have recently been studied in children with attention-deficit/hyperactivity disorder who have shown limited response to stimulants $[100,101]$ as well as in children with pervasive developmental disorder [102]. These small studies suggest improvements in attention disorders with the nAch-r agonist donepezil. A number of case reports $[103,104]$ and several clinical trials [105] with adult or mixed-age samples suggest possible benefit from donepezil, although again the data are limited. Tenovuo [106] reported his experience with a variety of nAch-r agonists in 111 subjects. At least a few of the subjects were children (aged 16-17 years), although no specific information was given about their response to treatment.

\section{DEPRESSION}

Depression is a common long-term sequela of TBI [107], with an incidence of between $26 \%$ and $77 \%$ of adult patients [107-111]. Features include negative affect, prominent anxiety symptoms, and executive dysfunction, and may greatly affect recovery from TBI [110]. Patients with depression tend to show greater functional disability and perceived cognitive impairment [107]. Fann et al [112] found benefit in treating post-TBI depression, with improvements noted in psychomotor speed, recent verbal memory, recent visual memory, general cognitive efficiency, and self-perception of cognitive symptoms. In this study, almost half of the patients with TBI were 19 years old and younger; 294 were younger than 9 years $(20.4 \%)$ and 411 were $10-19$ years $(28.5 \%)$.

The TCAs include imipramine, amitriptyline, desipramine, nortriptyline, and doxepin. Their precise mechanism of action is unclear, but they are thought to exert their effects by inhibiting the presynaptic reuptake of biogenic amines, primarily serotonin and norepinephrine. Newer evidence suggests that TCAs also modify the sensitivity of central serotonergic and $\beta$-adrenergic receptors. TCAs generally have a wider adverse effect profile than SSRIs. Because of their potentially adverse anticholinergic-mediated effects on cognition [111], they are not considered first-line agents in treating post-TBI depression. In addition, there is little evidence to support the efficacy of TCAs in treating post-TBI depression in either adult or pediatric patients. Furthermore, 
Wroblewski et al [113] suggested that TCAs may increase the incidence of seizures in patients with TBI. In this study, the medical records of 68 patients with severe brain injury were reviewed retrospectively in relation to their seizure histories, anticonvulsant use, and comedication use before, during, and after use of TCAs. The investigators concluded that 19\% of the study patients developed seizures largely beause of TCAs. When a TCA is used, nortriptyline is most commonly prescribed, likely because it is one of the best tolerated medications in this class.

The SSRIs include sertraline, fluoxetine, paroxetine, citalopram, escitalopram, and fluvoxamine. Although no largescale studies of their use in the pediatric TBI population are available, SSRIs are generally regarded as the first-line agents for treatment of depression in this age group [114]. Their efficacy in the adult TBI population has been studied more extensively. Case reports [115] demonstrate amelioration of depressive symptoms with $20 \mathrm{mg}$ a day of fluoxetine. Horsfield et al [116] performed an open-label pilot study of 5 adult patients with TBI by using fluoxetine at daily doses of 20-60 mg. The subjects were administered cognitive tests at baseline and after 8 months of treatment on fluoxetine. Fluoxetine not only improved mood but also improved performance on measures of basic attention and working memory.

Fann et al [68] found significant improvement in psychological and adaptive functioning with sertraline. They performed an 8-week, nonrandomized, placebo-run trial of 15 adults diagnosed with major depression between 3-24 months after mild TBI. Thirteen of the patients responded by week 8 of sertraline treatment. Patients who received sertraline showed significant reductions in psychological distress, anger, aggression, and postconcussive symptoms as well as improvements in global functioning. Sertraline doses ranged from 25 to $200 \mathrm{mg}$ daily by the end of the study period. Turner-Stokes et al [64] found sertraline to be useful and well tolerated in a cohort of 82 adult patients who presented with depression and were admitted to a brain injury rehabilitation program within a 15-month period. Response to sertraline was assessed prospectively in an open-label trial, with depression measured at pretreatment and at 6-8 weeks after initiation of sertraline. All of the patients who were depressed showed some level of improvement clinically, and no significant adverse effects were observed. Furthermore, $52 \%$ of the study subjects had previously failed to respond when using a different SSRI but still showed a significant positive response when changed to sertraline. These investigators concluded that sertraline appears to be useful and well tolerated in treating post-TBI depression. Ashman et al [66] performed a randomized, placebo-controlled trial of sertraline for the treatment of major depressive disorder in 52 adult patients after TBI, even an average of 17 years postinjury (range, 3-31 years postinjury). Oral sertraline in doses starting at $25 \mathrm{mg}$ and increasing to therapeutic levels (up to $200 \mathrm{mg}$ ) or a placebo was administered for 10 weeks. Although the drug and placebo groups did not differ on baseline measures of depression, anxiety, and quality of life, 59\% of the sertraline group showed a positive response to treatment, whereas only $32 \%$ of the placebo group showed a response. Thus, there is positive support in the adult literature for sertraline in treating depression after TBI. Again, however, there is a pressing need for pediatric-specific research.

Other SSRIs are not as well tolerated as sertraline in treating adult depression. Paroxetine may impair cognitive function, even in healthy adults, most likely as a result of its antimuscarinic effects [117]. Therefore, it is best used with caution, if at all, in patients with post-traumatic depression and cognitive complaints [65]. Bupropion is not recommended as a first-line agent for post-TBI depression because of concerns that it significantly lowers the seizure threshold. If bupropion is used in patients with TBI, then the sustainedrelease formulation is suggested but only after careful consideration of the patient's seizure risk [65]. No studies were found that addressed the pharmacologic treatment of depression after TBI in the pediatric population. Clinicians are cautioned to consider the FDA black box warning regarding increased risk of suicide in general pediatric populations being treated with SSRIs. Further studies are needed to determine the efficacy and safety of this class of medication in treating children with post-TBI depression.

\section{CONCLUSIONS}

Pediatric TBI results in numerous cognitive, motor, psychosocial, and behavioral sequelae. Although numerous agents are commonly used "off label," the evidence that supports these practices for children with TBI is limited to nonexistent at the present time. Although there is better evidence for many of the discussed agents in adults, caution must be used in extrapolating the efficacy and safety to children. The standard mantra is that "further research is needed." Although this is true, valid data are not easily obtained. With the wide variation in injury profile and recovery course after TBI, large numbers of subjects are necessary, and they must be followed up for extended periods of time to draw valid conclusions, particularly in a population in which a multitude of changes are taking place simply because of development. The need for rigorous study design and large sample sizes necessitates multicenter collaborations. The Children's Oncology Group (www.childrensoncologygroup.org) is an excellent example of collaborative research that produces meaningful results for relatively rare conditions and could serve as a model for developing pediatric TBI pharmacology studies.

A number of key issues must be considered when designing strong tests of efficacy and safety. Use of randomization or carefully matched control subject comparisons are ultimately the criterion standard. Researchers must avoid bias through 
the use of blinded trials. Standardizing operational definitions of key constructs (eg, agitation) and relevant assessment measures across research groups will assist direct comparison of findings. As we have demonstrated, current clinical practices for treatment of children after TBI are most often not well supported by hard data. In the present climate of evidence-based treatment, rigorously designed studies are critical in drawing conclusions regarding the efficacy and safety of neuropharmacologic treatment of children and adolescents after TBI.

\section{REFERENCES}

1. Schneier AJ, Shields BJ, Hostetler SG, Xiang H, Smith GA. Incidence of pediatric traumatic brain injury and associated hospital resource utilization in the United States. Pediatrics 2006;118:483-492.

2. Forum on Child and Family Statistics. Available from: http://childstats. gov. Accessed August 1, 2010.

3. Crooks CY, Zumsteg JM, Bell KR. Traumatic brain injury: a review of practice management and recent advances. Phys Med Rehabil Clin N Am 2007;18:681-710, vi.

4. Hugh J, Raghupathi R. New concepts in treatment of pediatric traumatic brain injury. Anesthesiol Clin 2009;27:213-240.

5. Priestley T, Horne AL, McKernan RM, Kemp JA. The effect of NMDA receptor glycine site antagonists on hypoxia-induced neurodegeneration of rat cortical cell cultures. Brain Res 1990;531:183-188.

6. Ikonomidou C, Turski L. Prevention of trauma-induced neurodegeneration in infant and adult rat brain: glutamate antagonists. Metab Brain Dis 1996;11:125-141.

7. Rao VL, Dogan A, Todd KG, Bowen KK, Dempsey RJ. Neuroprotection by memantine, a non-competitive NMDA receptor antagonist after traumatic brain injury in rats. Brain Res 2001;911:96-100.

8. Pohl D, Bittigau P, Ishimaru MJ, et al . N-methyl-D-aspartate antagonists and apoptotic cell death triggered by head trauma in developing rat brain. Proc Natl Acad Sci U S A 1999;96:2508-2513.

9. Muir KW. Glutamate-based therapeutic approaches: clinical trials with NMDA antagonists. Curr Opin Pharmacol 2006;6:53-60.

10. Ikonomidou $C$, Turski $L$. Why did NMDA receptor antagonists fail clinical trials for stroke and traumatic brain injury? Lancet Neurol 2002;1:383-386

11. Kemp JA, McKernan RM. NMDA receptor pathways as drug targets. Nat Neurosci 2002;5(Suppl):1039-1042.

12. Fujiki M, Kubo T, Kamida $T$, et al. Neuroprotective and antiamnesic effect of donepezil, a nicotinic acetylcholine-receptor activator, on rats with concussive mild traumatic brain injury. J Clin Neurosci 2008; 15:791-796.

13. Fujiki M, Kobayashi $H$, Uchida $S$, Inoue R, Ishii K. Neuroprotective effect of donepezil, a nicotinic acetylcholine-receptor activator, on cerebral infarction in rats. Brain Res 2005;1043:236-241.

14. Statler KD. Pediatric posttraumatic seizures: epidemiology, putative mechanisms of epileptogenesis and promising investigational progress. Dev Neurosci 2006;28:354-363.

15. Adelson PD, Bratton SL, Carney NA, et al. Guidelines for the acute medical management of severe traumatic brain injury in infants, children, and adolescents. Chapter 19. The role of anti-seizure prophylaxis following severe pediatric traumatic brain injury. Pediatr Crit Care Med 2003;4(Suppl):S72-S75.

16. Chiaretti A, De Benedictis R, Polidori G, Piastra M, Iannelli A, Di Rocco C. Early post-traumatic seizures in children with head injury. Childs Nerv Syst 2000;16:862-866

17. Szaflarski JP, Sangha KS, Lindsell CJ, Shutter LA. Prospective, randomized, single-blinded comparative trial of intravenous levetirac- etam versus phenytoin for seizure prophylaxis. Neurocrit Care 2010;12:165-172.

18. Wang $H$, Gao J, Lassiter $T F$, et al. Levetiracetam is neuroprotective in murine models of closed head injury and subarachnoid hemorrhage. Neurocrit Care 2006;5:71-78

19. Klitgaard H, Pitkanen A. Antiepileptogenesis, neuroprotection, and disease modification in the treatment of epilepsy: focus on levetiracetam. Epileptic Disord 2003;5(Suppl 1):S9-S16.

20. Alves OL, Doyle AJ, Clausen T, Gilman C, Bullock R. Evaluation of topiramate neuroprotective effect in severe TBI using microdialysis. Ann N Y Acad Sci 2003;993:25-34; discussion 48-53

21. Hoover RC, Motta M, Davis J, et al. Differential effects of the anticonvulsant topiramate on neurobehavioral and histological outcomes following traumatic brain injury in rats. J Neurotrauma 2004;21:501512

22. Tang V, Warden J, Cullen N, Rutledge E. Topiramate in traumatic brain injury: adverse effects on cognitive function. J Head Trauma Rehabil 2007;22:409-410.

23. Dolberg OT, Barkai G, Gross Y, Schreiber S. Differential effects of topiramate in patients with traumatic brain injury and obesity—a case series. Psychopharmacology (Berl) 2005;179:838-845.

24. McDonald CM, Jaffe KM, Fay GC, et al. Comparison of indices of traumatic brain injury severity as predictors of neurobehavioral outcome in children. Arch Phys Med Rehabil 1994;75:328-337.

25. Fridman EA, Calvar J, Bonetto $M$, et al. Fast awakening from minimally conscious state with apomorphine. Brain Inj 2009;23:172-177.

26. Aoki FY, Sitar DS. Clinical pharmacokinetics of amantadine hydrochloride. Clin Pharmacokinet 1988;14:35-51.

27. Green LB, Hornyak JE, Hurvitz EA. Amantadine in pediatric patients with traumatic brain injury: a retrospective, case-controlled study. Am J Phys Med Rehabil 2004;83:893-897.

28. McMahon MA, Vargus-Adams JN, Michaud LJ, Bean J. Effects of amantadine in children with impaired consciousness caused by acquired brain injury: a pilot study. Am J Phys Med Rehabil 2009;88: 525-532.

29. Patrick PD, Blackman JA, Mabry JL, Buck ML, Gurka MJ, Conaway MR. Dopamine agonist therapy in low-response children following traumatic brain injury. J Child Neurol 2006;21:879-885.

30. Patrick PD, Buck ML, Conaway MR, Blackman JA. The use of dopamine enhancing medications with children in low response states following brain injury. Brain Inj 2003;17:497-506.

31. Passler MA, Riggs RV. Positive outcomes in traumatic brain injuryvegetative state: patients treated with bromocriptine. Arch Phys Med Rehabil 2001;82:311-315.

32. Hornyak JE, Nelson VS, Hurvitz EA. The use of methylphenidate in paediatric traumatic brain injury. Pediatr Rehabil 1997;1:15-17.

33. Clauss RP, Güldenpfennig WM, Nel HW, Sathekge MM, Venkannagari RR. Extraordinary arousal from semi-comatose state on zolpidem. A case report. S Afr Med J 2000;90:68-72

34. Clauss $R, N e l W$. Drug induced arousal from the permanent vegetative state. NeuroRehabilitation 2006;21:23-28

35. Cohen SI, Duong TT. Increased arousal in a patient with anoxic brain injury after administration of zolpidem. Am J Phys Med Rehabil 2008;87:229-231.

36. Whyte J, Myers R. Incidence of clinically significant responses to zolpidem among patients with disorders of consciousness: a preliminary placebo controlled trial. Am J Phys Med Rehabil 2009;88:410418

37. Kawecki Z, Kwiatkowski S, Grzegorzewski P, Szlachta Jezioro I. Sudden improvement of all neurological functions after general anesthesia and two-day intrathecal infusion of baclofen in a child with primary brain-stem injury [in Polish]. Przegl Lek 2007;64(Suppl 2):13-14 
38. Sarà M, Pistoia F, Mura E, Onorati $\mathrm{P}$, Govoni S. Intrathecal baclofen in patients with persistent vegetative state: 2 hypotheses. Arch Phys Med Rehabil 2009;90:1245-1249.

39. Sarà M, Sacco S, Cipolla F, et al. An unexpected recovery from permanent vegetative state. Brain Inj 2007;21:101-103.

40. Taira $T$, Hori $T$. Intrathecal baclofen in the treatment of post-stroke central pain, dystonia, and persistent vegetative state. Acta Neurochir Suppl 2007:97:227-229.

41. Lequerica AH, Rapport LJ, Loeher K, Axelrod BN, Vangel SJ Jr, Hanks RA. Agitation in acquired brain injury: impact on acute rehabilitation therapies. J Head Trauma Rehabil 2007;22:177-183.

42. Fugate LP, Spacek LA, Kresty LA, Levy CE, Johnson JC, Mysiw WJ. Definition of agitation following traumatic brain injury: I. A survey of the Brain Injury Special Interest Group of the American Academy of Physical Medicine and Rehabilitation. Arch Phys Med Rehabil 1997; 78:917-923.

43. Mysiw WJ, Jackson RD, Corrigan JD. Amitriptyline for post-traumatic agitation. Am J Phys Med Rehabil 1988;67:29-33.

44. Fleminger S, Greenwood RJ, Oliver DL. Pharmacological management for agitation and aggression in people with acquired brain injury. Cochrane Database Syst Rev 2006(4):CD003299.

45. Francisco GE, Walker WC, Zasler ND, Bouffard MH. Pharmacological management of neurobehavioural sequelae of traumatic brain injury: a survey of current physiatric practice. Brain Inj 2007;21:1007-1014.

46. Goldstein LB. Prescribing of potentially harmful drugs to patients admitted to hospital after head injury. J Neurol Neurosurg Psychiatry 1995; $58: 753-755$

47. Wroblewski BA, Joseph AB. The use of intramuscular midazolam for acute seizure cessation or behavioral emergencies in patients with traumatic brain injury. Clin Neuropharmacol 1992;15:44-49.

48. Perna R. Benzodiazepines and antipsychotics: cognitive side effects. J Head Trauma Rehabil 2004;19:516-518.

49. Goldstein LB. Basic and clinical studies of pharmacologic effects on recovery from brain injury. J Neural Transplant Plast 1993;4:175192.

50. Cotton BA, Snodgrass KB, Fleming SB, et al. Beta-blocker exposure is associated with improved survival after severe traumatic brain injury. J Trauma 2007;62:26-33; discussion 33-35.

51. Brooke MM, Patterson DR, Questad KA, Cardenas D, Farrel-Roberts L. The treatment of agitation during initial hospitalization after traumatic brain injury. Arch Phys Med Rehabil 1992;73:917-921.

52. Massagli TL. Neurobehavioral effects of phenytoin, carbamazepine, and valproic acid: implications for use in traumatic brain injury. Arch Phys Med Rehabil 1991;72:219-226.

53. Kossoff EH, Bergey GK, Freeman JM, Vining EP. Levetiracetam psychosis in children with epilepsy. Epilepsia 2001;42:1611-1613.

54. Bootsma HP, Aldenkamp AP, Diepman L, et al. The effect of antiepileptic drugs on cognition: patient perceived cognitive problems of topiramate versus levetiracetam in clinical practice. Epilepsia 2006; 47(Suppl 2):24-27.

55. Chatham Showalter PE, Kimmel DN. Agitated symptom response to divalproex following acute brain injury. J Neuropsychiatry Clin Neurosci 2000;12:395-397.

56. Wroblewski BA, Joseph AB, Kupfer J, Kalliel K. Effectiveness of valproic acid on destructive and aggressive behaviours in patients with acquired brain injury. Brain Inj 1997;11:37-47.

57. Chatham-Showalter PE. Carbamazepine for combativeness in acute traumatic brain injury. J Neuropsychiatry Clin Neurosci 1996;8:9699.

58. Azouvi P, Jokic C, Attal N, Denys P, Markabi S, Bussel B. Carbamazepine in agitation and aggressive behaviour following severe closedhead injury: results of an open trial. Brain Inj 1999;13:797-804.

59. Pachet A, Friesen S, Winkelaar D, Gray S. Beneficial behavioural effects of lamotrigine in traumatic brain injury. Brain Inj 2003;17: 715-722.
60. Cipriani A, Santilli C, Furukawa TA, et al. Escitalopram versus other antidepressive agents for depression. Cochrane Database Syst Rev 2009(2):CD006532.

61. Fugate LP, Spacek LA, Kresty LA, Levy CE, Johnson JC, Mysiw WJ Measurement and treatment of agitation following traumatic brain injury: II. A survey of the Brain Injury Special Interest Group of the American Academy of Physical Medicine and Rehabilitation. Arch Phys Med Rehabil 1997;78:924-928.

62. Reinhard DL, Whyte J, Sandel ME. Improved arousal and initiation following tricyclic antidepressant use in severe brain injury. Arch Phys Med Rehabil 1996;77:80-83

63. Jackson RD, Corrigan JD, Arnett JA. Amitriptyline for agitation in head injury. Arch Phys Med Rehabil 1985;66:180-181.

64. Turner-Stokes L, Hassan N, Pierce K, Clegg F. Managing depression in brain injury rehabilitation: the use of an integrated care pathway and preliminary report of response to sertraline. Clin Rehabil 2002;16: 261-268.

65. Silver JM, McAllister TW, Arciniegas DB. Depression and cognitive complaints following mild traumatic brain injury. Am J Psychiatry 2009; 166:653-661

66. Ashman TA, Cantor JB, Gordon WA, et al. A randomized controlled trial of sertraline for the treatment of depression in persons with traumatic brain injury. Arch Phys Med Rehabil 2009;90:733-740.

67. Lee H, Kim SW, Kim JM, Shin IS, Yang SJ, Yoon JS. Comparing effects of methylphenidate, sertraline and placebo on neuropsychiatric sequelae in patients with traumatic brain injury. Hum Psychopharmacol 2005;20:97-104.

68. Fann JR, Uomoto JM, Katon WJ. Sertraline in the treatment of major depression following mild traumatic brain injury. J Neuropsychiatry Clin Neurosci 2000;12:226-232

69. Kant R, Smith-Seemiller L, Zeiler D, Treatment of aggression and irritability after head injury. Brain Inj 1998;12:661-666.

70. Meythaler JM, Depalma L, Devivo MJ, Guin-Renfroe S, Novack TA. Sertraline to improve arousal and alertness in severe traumatic brain injury secondary to motor vehicle crashes. Brain Inj 2001;15:321331.

71. Zafonte RD, Cullen N, Lexell J. Serotonin agents in the treatment of acquired brain injury. J Head Trauma Rehabil 2002;17:322-334.

72. Müller $U$, Murai $T$, Bauer-Wittmund $T$, von Cramon DY. Paroxetine versus citalopram treatment of pathological crying after brain injury. Brain Inj 1999;13:805-811.

73. Sloan RL, Brown KW, Pentland B. Fluoxetine as a treatment for emotional lability after brain injury. Brain Inj 1992;6:315-319.

74. Kline AE, Hoffman AN, Cheng JP, Zafonte RD, Massucci JL. Chronic administration of antipsychotics impede behavioral recovery after experimental traumatic brain injury. Neurosci Lett 2008;448:263267

75. Kline AE, Massucci JL, Zafonte RD, Dixon CE, DeFeo JR, Rogers EH. Differential effects of single versus multiple administrations of haloperidol and risperidone on functional outcome after experimental brain trauma. Crit Care Med 2007;35:919-924.

76. Hoffman AN, Cheng JP, Zafonte RD, Kline AE. Administration of haloperidol and risperidone after neurobehavioral testing hinders the recovery of traumatic brain injury-induced deficits. Life Sci 2008;83 602-607.

77. Stanislav SW. Cognitive effects of antipsychotic agents in persons with traumatic brain injury. Brain Inj 1997;11:335-341

78. Elovic EP, Lansang R, Li Y, Ricker JH. The use of atypical antipsychotics in traumatic brain injury. J Head Trauma Rehabil 2003;18:177195.

79. Gardner DM, Baldessarini RJ, Waraich P. Modern antipsychotic drugs: a critical overview. CMAJ 2005;172:1703-1711.

80. Horacek J, Bubenikova-Valesova V, Kopecek M, et al. Mechanism of action of atypical antipsychotic drugs and the neurobiology of schizophrenia. CNS Drugs 2006;20:389-409. 
81. Allison DB, Mentore JL, Heo M, et al. Antipsychotic-induced weight gain: a comprehensive research synthesis. Am J Psychiatry 1999;156: 1686-1696.

82. Wilkinson R, Meythaler JM, Guin-Renfroe S. Neuroleptic malignant syndrome induced by haloperidol following traumatic brain injury. Brain Inj 1999;13:1025-1031.

83. Kadyan V, Colachis SC, Depalma MJ, Sanderson JD, Mysiw WJ. Early recognition of neuroleptic malignant syndrome during traumatic brain injury rehabilitation. Brain Inj 2003;17:631-637.

84. Caroff SN, Mann SC. Neuroleptic malignant syndrome. Med Clin North Am 1993;77:185-202.

85. Bellamy CJ, Kane-Gill SL, Falcione BA, Seybert AL. Neuroleptic malignant syndrome in traumatic brain injury patients treated with haloperidol. J Trauma 2009;66:954-958.

86. Stanislav SW, Childs A. Evaluating the usage of droperidol in acutely agitated persons with brain injury. Brain Inj 2000;14:261-265.

87. Michals ML, Crismon ML, Roberts S, Childs A. Clozapine response and adverse effects in nine brain-injured patients. J Clin Psychopharmacol 1993;13:198-203.

88. Newcomer JW. Second-generation (atypical) antipsychotics and metabolic effects: a comprehensive literature review. CNS Drugs 2005; 19(Suppl 1):1-93.

89. Noé E, Ferri J, Trénor C, Chirivella J. Efficacy of ziprasidone in controlling agitation during post-traumatic amnesia. Behav Neurol 2007;18:7-11.

90. Scott LK, Green R, McCarthy PJ, Conrad SA. Agitation and/or aggression after traumatic brain injury in the pediatric population treated with ziprasidone. Clinical article. J Neurosurg Pediatr 2009;3:484487.

91. Kim E, Bijlani M. A pilot study of quetiapine treatment of aggression due to traumatic brain injury. J Neuropsychiatry Clin Neurosci 2006; 18:547-549

92. Oster TJ, Anderson CA, Filley CM, Wortzel HS, Arciniegas DB. Quetiapine for mania due to traumatic brain injury. CNS Spectr 2007;12:764-769

93. Daniels JP, Felde A. Quetiapine treatment for mania secondary to brain injury in 2 patients. J Clin Psychiatry 2008;69:497-498.

94. Wilson MS, Gibson CJ, Hamm RJ. Haloperidol, but not olanzapine, impairs cognitive performance after traumatic brain injury in rats. Am J Phys Med Rehabil 2003;82:871-879.

95. Levin HS, Hanten G, Executive functions after traumatic brain injury in children. Pediatr Neurol 2005;33:79-93.

96. Arnsten AFT. Stimulants: therapeutic Actions in ADHD. Neuropsychopharmacology 2006;31:2376-2383.

97. Gualtieri CT, Evans RW. Stimulant treatment for the neurobehavioural sequelae of traumatic brain injury. Brain Inj 1988;2:273-290.

98. Williams SE, Ris MD, Ayyangar R, Schefft BK, Berch D. Recovery in pediatric brain injury: is psychostimulant medication beneficial? J Head Trauma Rehabil 1998;13:73-81

99. Mahalick DM, Carmel PW, Greenberg JP, et al. Psychopharmacologic treatment of acquired attention disorders in children with brain injury. Pediatr Neurosurg 1998;29:121-126.
100. Wilens TE, Biederman J, Wong J, Spencer TJ, Prince JB. Adjunctive donepezil in attention deficit hyperactivity disorder youth: case series. J Child Adolesc Psychopharmacol 2000;10:217-222.

101. Wilens TE, Waxmonsky J, Scott M, et al. An open trial of adjunctive donepezil in attention-deficit/hyperactivity disorder. J Child Adolesc Psychopharmacol 2005; 15:947-955.

102. Doyle RL, Frazier J, Spencer TJ, Geller D, Biederman J, Wilens T. Donepezil in the treatment of ADHD-like symptoms in youths with pervasive developmental disorder: a case series. J Atten Disord 2006; 9:543-549.

103. Bourgeois JA, Bahadur N, Minjares S. Donepezil for cognitive deficits following traumatic brain injury: a case report. J Neuropsychiatry Clin Neurosci 2002; 14:463-464.

104. Foster M, Spiegel DR. Use of donepezil in the treatment of cognitive impairments of moderate traumatic brain injury. J Neuropsychiatry Clin Neurosci 2008;20:106.

105. Ballesteros J, Güemes I, Ibarra N, Quemada JI. The effectiveness of donepezil for cognitive rehabilitation after traumatic brain injury: a systematic review. J Head Trauma Rehabil 2008;23:171-180.

106. Tenovuo $O$. Central acetylcholinesterase inhibitors in the treatment of chronic traumatic brain injury-clinical experience in 111 patients. Prog Neuropsychopharmacol Biol Psychiatry 2005;29:61-67.

107. Fann JR, Katon WJ, Uomoto JM, Esselman PC. Psychiatric disorders and functional disability in outpatients with traumatic brain injuries. Am J Psychiatry 1995;152:1493-1499.

108. Himanen L, Portin R, Tenovuo O, et al. Attention and depressive symptoms in chronic phase after traumatic brain injury. Brain Inj 2009;23:220-227.

109. Koponen S, Taiminen $T$, Portin R, et al. Axis I and II psychiatric disorders after traumatic brain injury: a 30-year follow-up study. Am J Psychiatry 2002;159:1315-1321.

110. Jorge RE, Robinson RG, Moser D, Tateno A, Crespo-Facorro B, Arndt S. Major depression following traumatic brain injury. Arch Gen Psychiatry 2004;61:42-50.

111. Arciniegas DB, Silver JM. Pharmacotherapy of posttraumatic cognitive impairments. Behav Neurol 2006;17:25-42.

112. Fann JR, Uomoto JM, Katon WJ. Cognitive improvement with treatment of depression following mild traumatic brain injury. Psychosomatics 2001;42:48-54

113. Wroblewski BA, McColgan $K$, Smith $K$, Whyte J, Singer WD. The incidence of seizures during tricyclic antidepressant drug treatment in a brain-injured population. J Clin Psychopharmacol 1990;10:124128.

114. Warden DL, Gordon B, McAllister TW, et al. Guidelines for the pharmacologic treatment of neurobehavioral sequelae of traumatic brain injury. J Neurotrauma 2006;23:1468-1501.

115. Bessette RF, Peterson LG. Fluoxetine and organic mood syndrome. Psychosomatics 1992;33:224-226.

116. Horsfield SA, Rosse RB, Tomasino V, Schwartz BL, Mastropaolo J, Deutsch SI. Fluoxetine's effects on cognitive performance in patients with traumatic brain injury. Int J Psychiatry Med 2002;32:337-344.

117. Schmitt JA, Kruizinga MJ, Riedel WJ. Non-serotonergic pharmacological profiles and associated cognitive effects of serotonin reuptake inhibitors. J Psychopharmacol 2001;15:173-179. 